\title{
Developing corporate environment and health strategy: review of existing corporate citizenship (CC) models
}

\author{
K. Duncan \\ Health Studies, University of Toronto at Scarborough, Canada
}

\begin{abstract}
Corporate citizenship usually encompasses the following responsibilities: business standards; community relations; education and leadership development; employee relations; environment protection; and health promotion.

As corporations around the world extend their vision to society, they require models of corporate citizenship (CC) in order to help develop corporate environment and health strategy. Unfortunately, there is little agreement as to which models may prove suitable in the development of environmental and health strategy, as no systematic review of the major $\mathrm{CC}$ models has been undertaken.

As a result, this paper reviews almost fifty CC models (1960-2000), and suggests a new typology for models - one that reflects the process that business practitioners would follow in developing an overall corporate citizenship strategy. Business leaders would first choose a model, next a decision-making tool, then determine processes to be followed with stakeholders, and finally report on their environmental and health performance.
\end{abstract}

Keywords: corporate citizenship models, environment, health, strategy.

\section{Introduction}

Because corporate citizenship has been developing since the 1950s, researchers and organizations have proposed a multitude of models, many of which are shown in Table 1. 


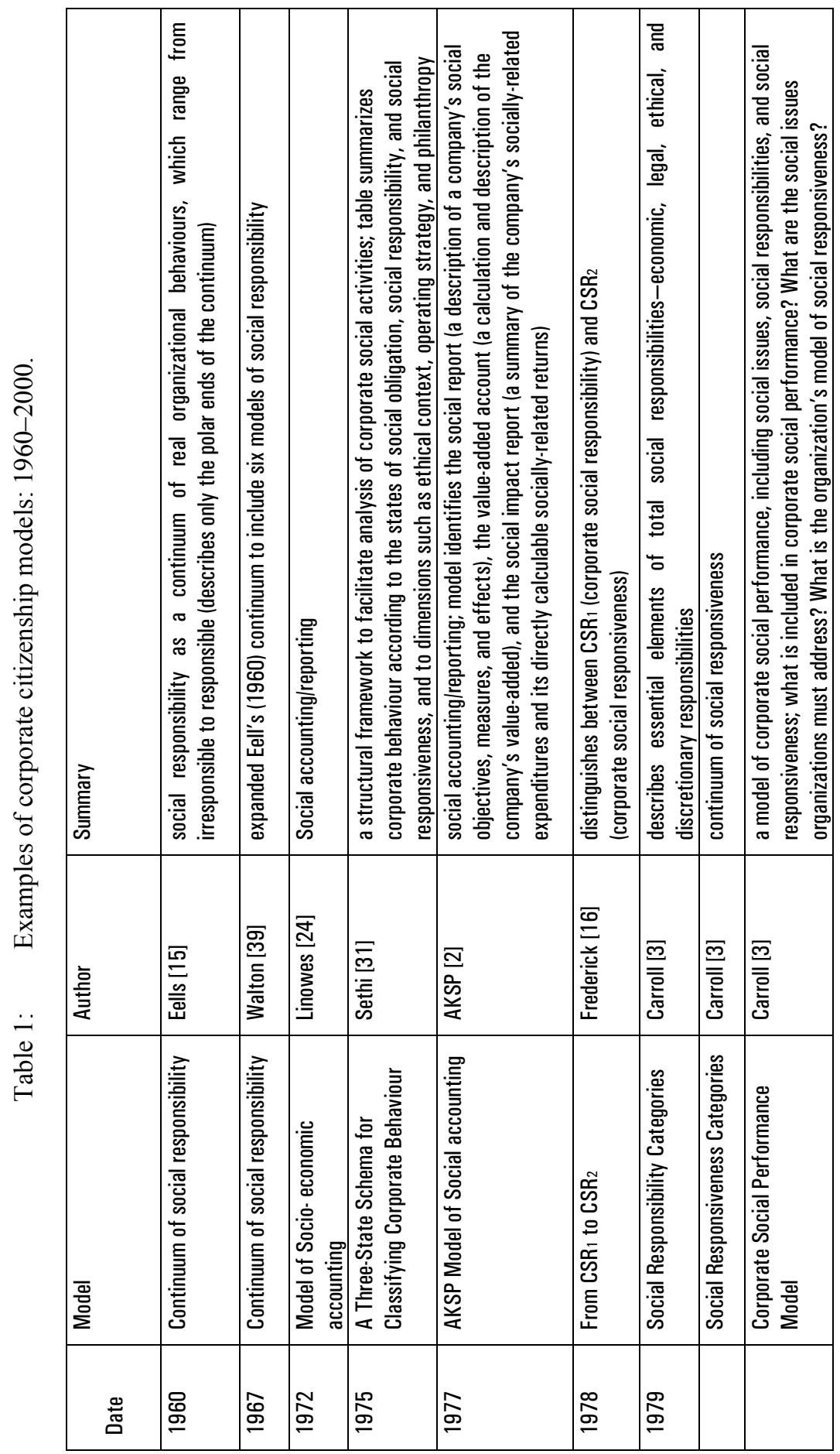




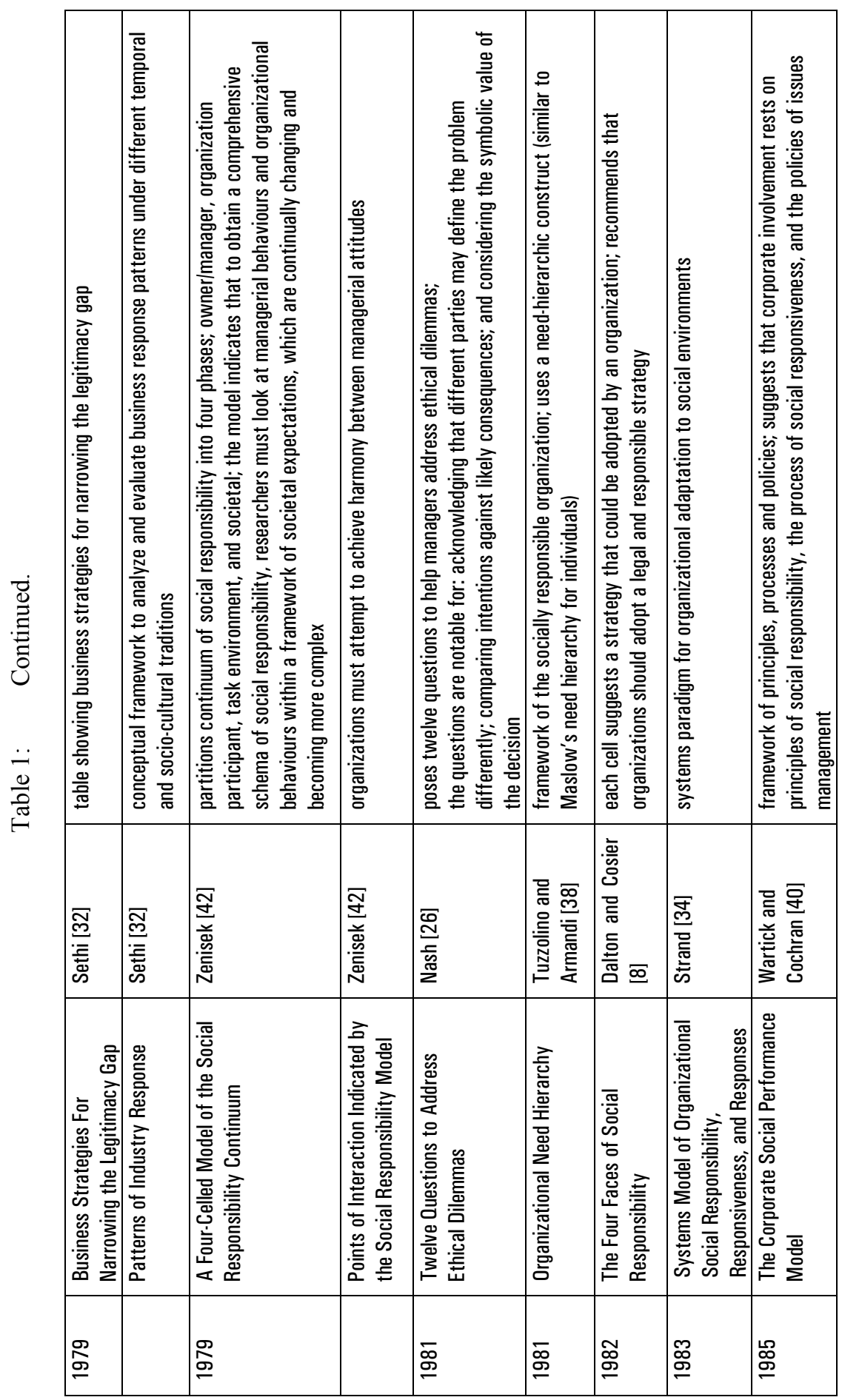

WIT Transactions on Ecology and the Environment, Vol 110, (C) 2008 WIT Press www.witpress.com, ISSN 1743-3541 (on-line) 


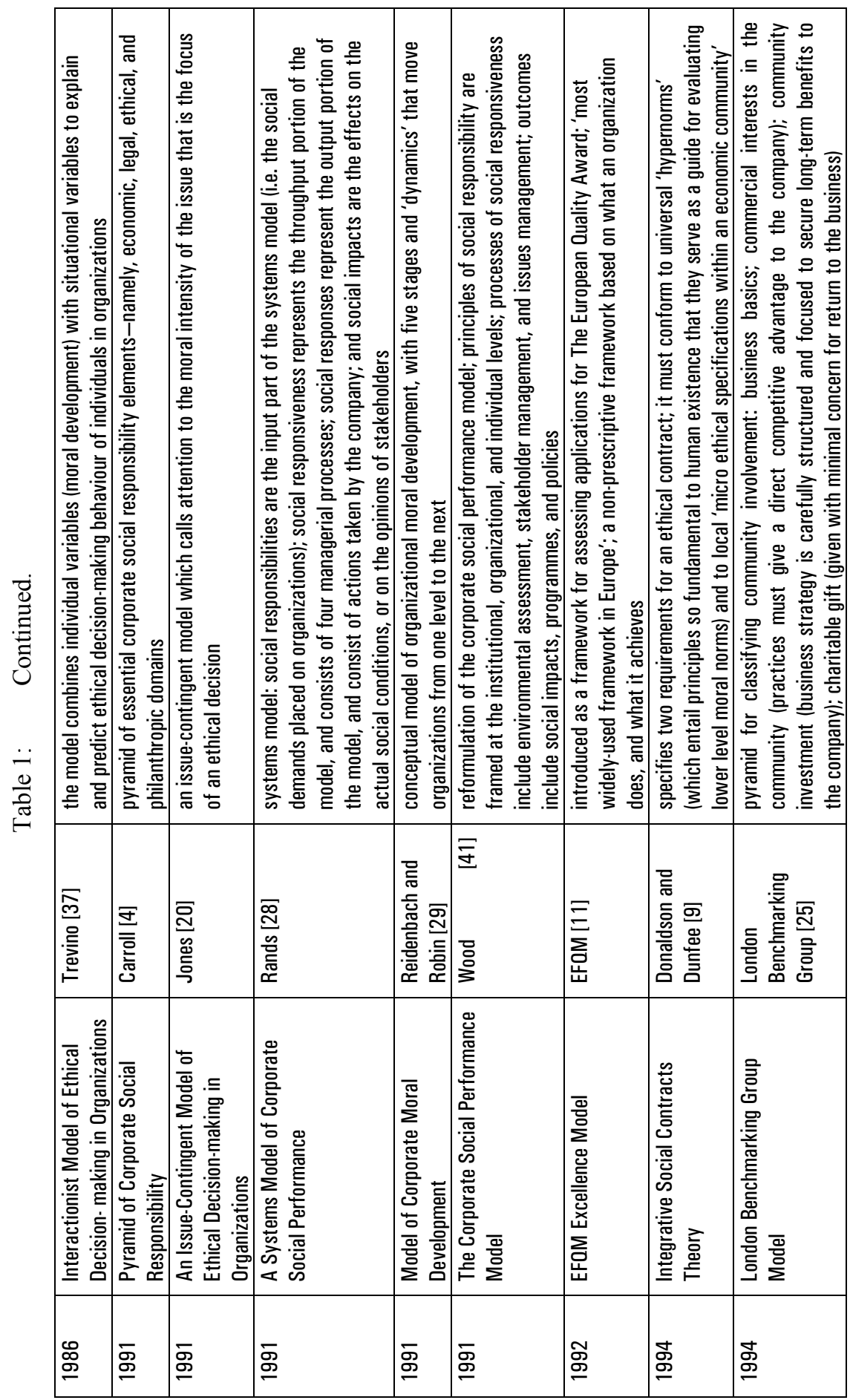

WIT Transactions on Ecology and the Environment, Vol 110, (C) 2008 WIT Press www.witpress.com, ISSN 1743-3541 (on-line) 


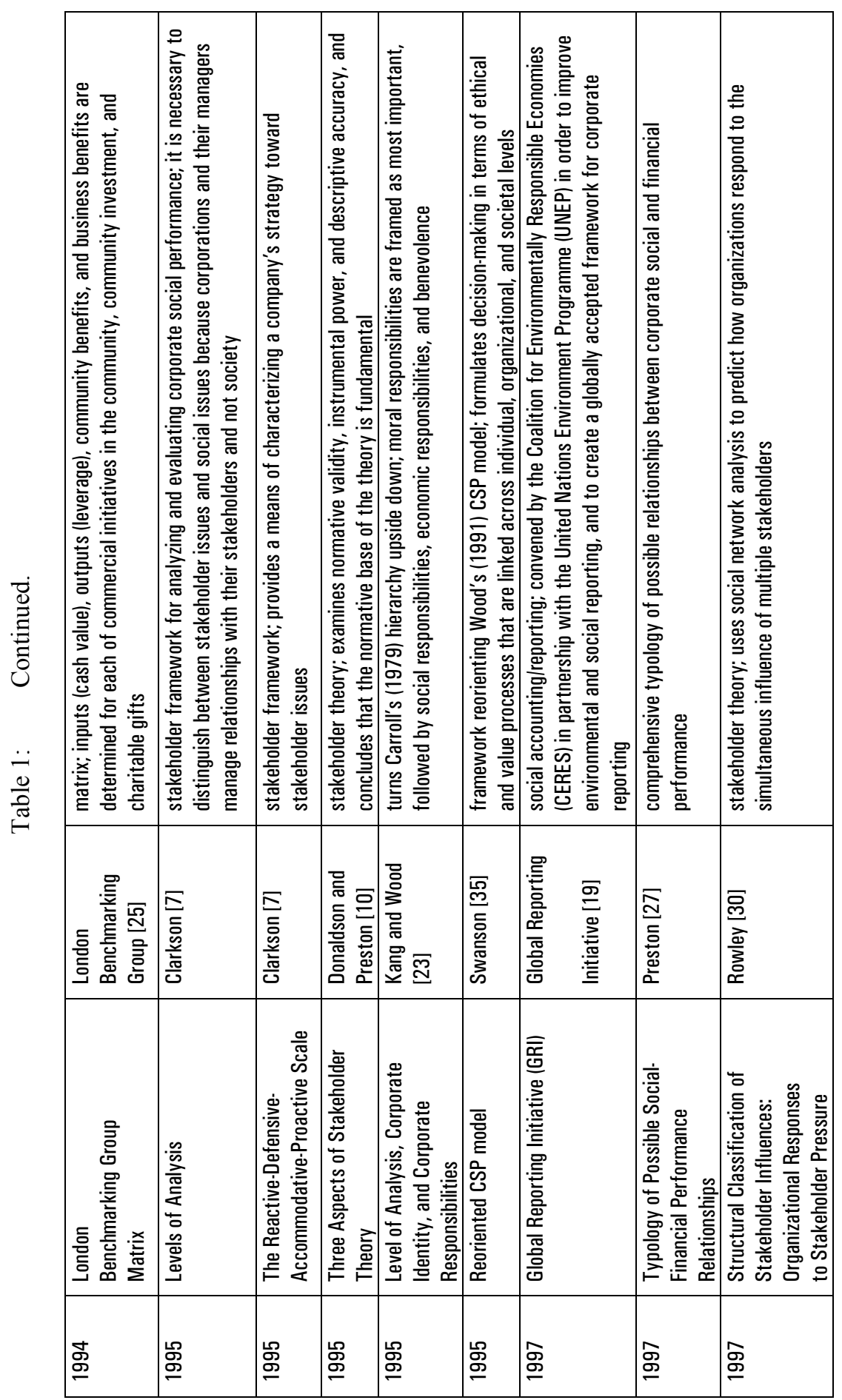

WIT Transactions on Ecology and the Environment, Vol 110, (C) 2008 WIT Press www.witpress.com, ISSN 1743-3541 (on-line) 


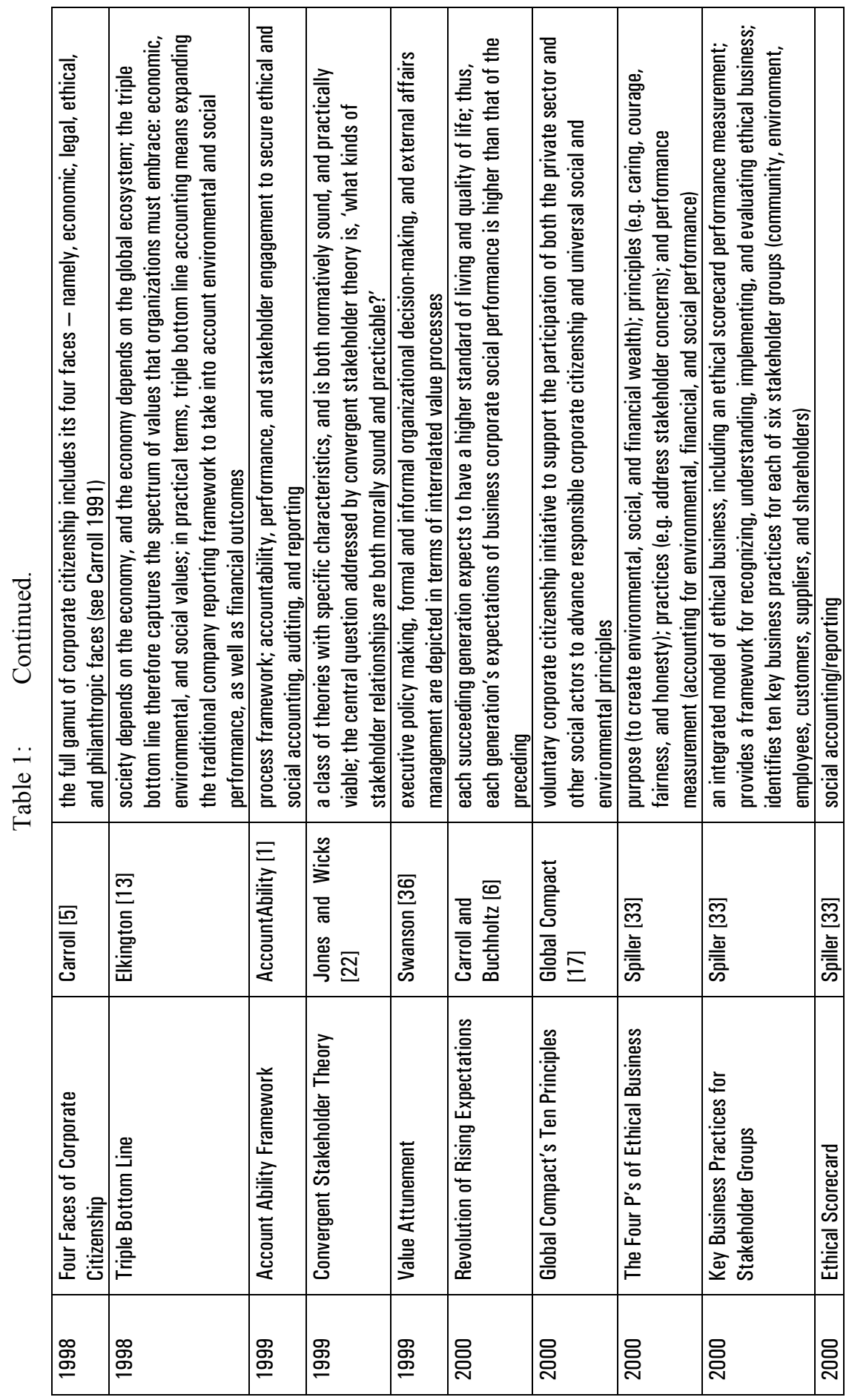

WIT Transactions on Ecology and the Environment, Vol 110, (C) 2008 WIT Press www.witpress.com, ISSN 1743-3541 (on-line) 


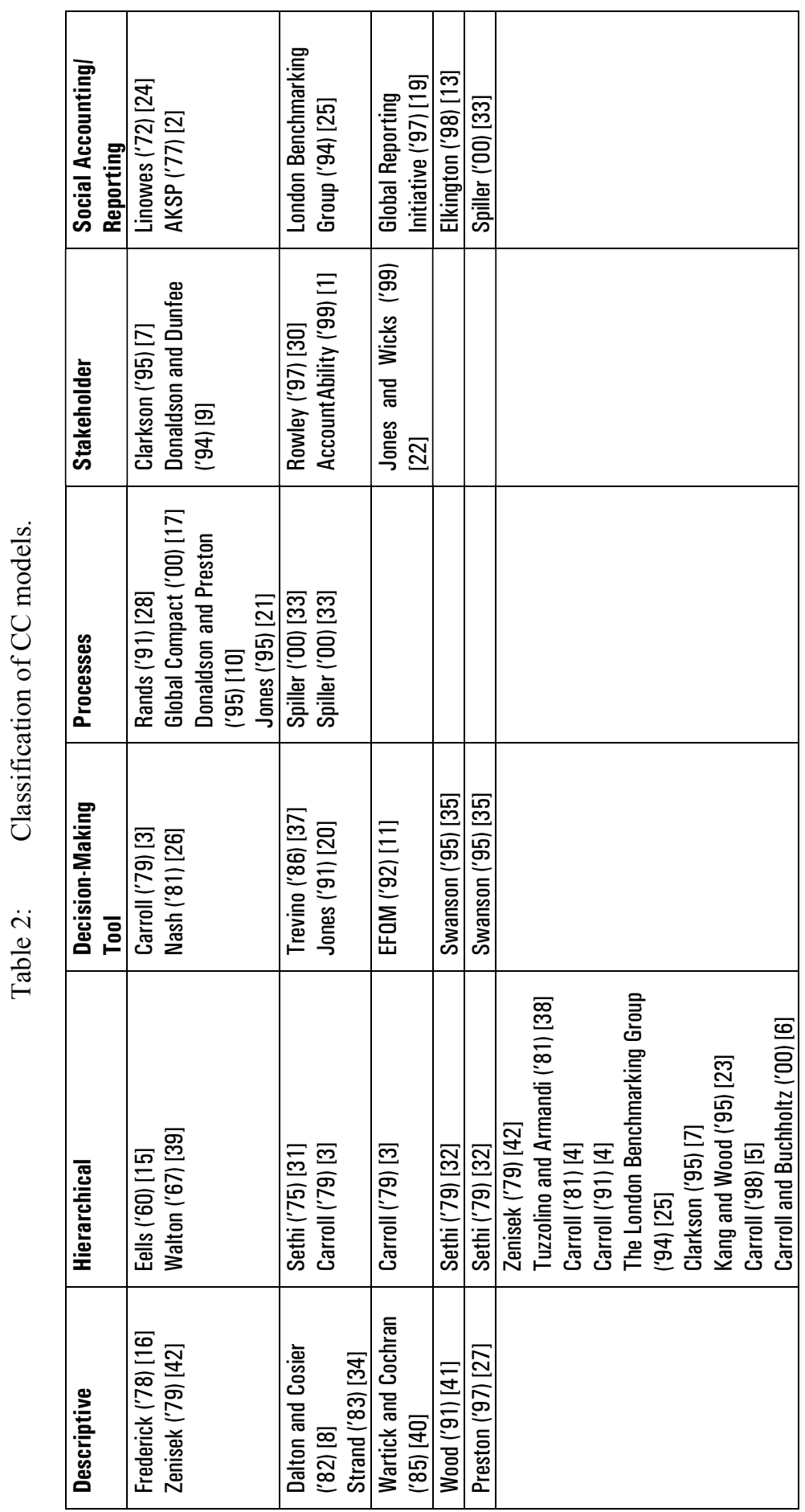




\section{Discussion}

In order to make sense of the above table, this paper suggests the following typology of CC models: descriptive models (explain methods of viewing and understanding $\mathrm{CC}$ ); hierarchical models; decision-making tools (help executives and managers make decisions concerning CC strategy); process models (provide complex decision-making processes for managers); stakeholder models (require corporations to promote the interests of all stakeholders); and social accounting/reporting models. Table 2 uses the new classification to categorize the models found in Table 1.

\section{Conclusion}

In conclusion, the above classification reflects the process that business practitioners would follow in developing an overall corporate citizenship strategy. That is, business leaders would first choose a model (descriptive or hierarchical), next a decision-making tool, then determine processes to be followed with stakeholders, and finally report on their environmental/health performance.

\section{References}

[1] AccountAbility. 1999. AccountAbility framework. http://www. accountability.org/aa1000/default.asp.

[2] Antal, A., Dierkes, M., MacMillan, K., and Manz, L. 2002. Corporate social reporting revisited. Journal of General Management 28 (2): $22-44$.

[3] Carroll, A. 1979. A three-dimensional conceptual model of corporate performance. Academy of Management Review 4 (4): 497-505.

[4] Carroll, A. 1991. The pyramid of corporate social responsibility: toward the moral management of organizational stakeholders. Business Horizons July/August: $39-48$.

[5] Carroll, A. 1998. The four faces of corporate citizenship. Business and Society Review 100/101: 1-7.

[6] Carroll, A. and Buchholtz, A. 2000. Business and Society: Ethics and Stakeholder Management ( $4^{\text {th }}$ edition). South-Western Publishing.

[7] Clarkson, M. 1995. A stakeholder framework for analyzing and evaluating corporate social performance. Academy of Management Review 20: 92117.

[8] Dalton, D. and Cosier, R. 1982. The four faces of social responsibility. Business Horizons 19-27.

[9] Donaldson, T. and Dunfee, T. 1994. Toward a unified conception of business ethics: integrative social contract theory. Academy of Management Review 19 (2): 52-84. 
[10] Donaldson, T. and Preston, L.1995.The stakeholder theory of the corporation. Concepts, evidence, and implications. Academy of Management Review 20: 65-91.

[11] EFQM Excellence Model. 1992.

[12] http://www.efqm.org/model_awards/model/excellence_model.htm.

[13] Elkington, J. 1998. Cannibals with Forks: The Triple Bottom Line of the $21^{\text {st }}$ Century Business. New Society Publishers: British Columbia.

[14] Eells, R. 1956. Corporate Giving in a Free Society. New York.

[15] Eells, R. 1960. The Meaning of Modern Business. Columbia University Press: New York.

[16] Frederick, W. 1978. From CSR1 to CSR2. Business and Society 33 (2): 150-64.

[17] Global Compact. 2000.

[18] http://www.unglobalcompact.org/Portal/?NavigationTarget=/roles/portal_u ser/aboutTheGC/nf/nf/theNinePrinciples.

[19] GRI. 2002. Sustainability Reporting Guidelines. Global Reporting Initiative: Boston. http://www.globalreporting.org/about/initiatives.asp.

[20] Jones, T. 1991. Ethical decision-making by individuals in organizations: an issue-contingent model. Academy of Management Review 6(2): 366-95.

[21] Jones, T. 1995. Instrumental stakeholder theory: a synthesis of ethics and economics. Academy of Management Review 20: 404-37.

[22] Jones, T. and Wicks, A. 1999. Convergent stakeholder theory. Academy of Management Review 24: 206-21.

[23] Kang, Y. and Wood, D. 1995. Before-profit social responsibility-turning the economic paradigm upside down. In: Nigh, D. and Collins, D. (eds.). Proceedings of the Sixth Annual Meeting of the International Association of Business and Society. Vienna, 1995.

[24] Linowes, D. 1972. An approach to socio-economic accounting. The Conference Board RECORD.

[25] London Benchmarking Group. 1994. The London Benchmarking Group model. http://www.corporatecitizenship.co.uk/benchmark.html.

[26] Nash, L. (1981). Ethics without the sermon. Harvard Business Review 59.

[27] Preston, L. 1975. Corporation and society: the search for a paradigm. Journal of Economic Literature 13: 434-53.

[28] Rands, G. 1991. The corporate social performance model, revisited. In Proceedings of the Second Annual Meeting of the International Association for Business and Society.

[29] Reidenbach, R. and Robin, D.1991. A conceptual model of corporate moral development. Journal of Business Ethics 10: 273-286.

[30] Rowley, T. 1997. Moving beyond dyadic ties: a network theory of stakeholder influences. Academy of Management Review 22 (4): 887-910.

[31] Sethi, 1975. Dimensions of corporate social performance: an analytical framework. California Management Review Spring: 58-64.

[32] Sethi, 1979. A conceptual framework for environmental analysis of social issues and evolution of business responsibility patterns. Academy of Management Review 4(1): 63-74. 
[33] Spiller, R. 2000. Ethical business and investment: a model for business and society. Vol. 27, Iss. 1/2: 149-160.

[34] Strand, R. 1983. A systems paradigm of organizational adaptations to the social environment. Academy of Management Review 8: 90-6.

[35] Swanson, D. 1995. Addressing a theoretical problem by reorienting the corporate social performance model. Academy of Management Review 20 (1): 43-64.

[36] Swanson, D. 1999. Toward an integrative theory of business and society: a research strategy for corporate social performance. Academy of Management Review 24 (93): 506-21.

[37] Trevino, L. 1990. Ethical decision-making in organizations: a personsituation interactionist model. Academy of Management Review 11: 614.

[38] Tuzzolino, F. and Armandi, B. 1981. A need-hierarchy framework for assessing corporate social responsibility. Academy of Management Review 6: 21-28.

[39] Walton, C. 1967. Corporate Social Responsibilities. Wadsworth: California.

[40] Wartick, S. and Cochran, P. 1985. The evolution of the corporate social performance model. Academy of Management Review 10 (4): 758-69.

[41] Wood, D.1991.Corporate social performance revisited. Academy of Management Review 16(4): 691-718.

[42] Zenisek, T. 1979. Corporate social responsibility: a conceptualization based on organizational literature. Academy of Management Review 4: 359-68. 